\title{
How One Idea Almost Became Law: A Case Study Jon Marc Taylor
}

D uring the summer of 1996, I had an epiphany. If the State of Missouri received $\$ 3$ million in rebates (unknown at the time to rise shortly thereafter to $\$ 10$ million per annum) from the MCI-WORLDCOM Inmate Phone System contract, why not use that money to replace the Pell Grants, a post-secondary education subsidy program that prisoners had been excluded from the year before by a myopic Congress? The following case study chronicles the step-by-step efforts made to transform the concept into legislative reality, as well as some of the challenges we faced.

\section{The Process}

The first step was to draft a white paper of the concept to communicate the idea to a larger audience, and then to have the article published for wider dissemination. "Calling for Sheepskins" was prominently published in the Winter 1996-1997 issue of the Cry Justice Journal':

In 1994, two related yet apparently unassociated events occurred in Missouri prisons. First, all college programs were closed down. Second, the State General Fund received nearly three million dollars in rebates from the MCI Corporation. [...]

For the past half-century, poll after poll has shown public support for "treating" or "rehabilitating" those incarcerated, in order that they would not return to crime when released. Even one of the main sponsors of the legislation mounted to discontinue prisoners' eligibility for Pell Grants, Representative Bart Gordon [D-Tennessee], was not opposed to prisoners' higher education. The problem, he stated, was "not whether prisoners should be educated, but whether Pell Grants are an appropriate vehicle to do that." Since federal funds to finance college curriculum in Missouri prisons are no longer available, a new funding source needs to be found. A primary criticism of prisoners receiving Pell Grants was concern over the use of tax dollars to pay for inmates' educations, which was viewed by some to be "rewarding" criminal behaviour. In today's climate of tight state budgets, and struggles to house and feed ever-expanding prison populations, finding 
state tax money to reinstate higher education for people who have been convicted seems a fruitless proposition. [...] Legislation should be introduced that would direct revenue from the inmate phone system into the inmate canteen fund, specifically earmarked to fund postsecondary education. The canteen fund could mirror the formula of Pell Grants, matching the amount awarded with the amount a prisoner would have received if eligible for the Pell program. [...]

If this legislation were passed, each time someone accepted a call from a prisoner, they would be helping to send one through college. In this small way they would be enriching many futures by increasing the likelihood that prisoners will be successfully rehabilitated, thus making their own neighbourhoods safer for everyone's children.

The article was well received with copies distributed well beyond the subscription base of the Cry Justice Journal. The second step was to craft a lobbying strategy to have legislation introduced and passed. This required the creation of a proposal kit, recruiting a lobbyist, and targeting likely representatives to support the measure. The Proposal for the Recommencement of Post-Secondary Education Opportunities in Missouri Prisons kit was compiled and produced with the resources we had available at the prison. ${ }^{2}$ It consisted of four sections from the "Sheepskins" article, and half a dozen related pieces from substantial publications. ${ }^{3}$ As for a lobbyist, we lucked out with a sweet, physically frail, elderly Catholic nun with a beauteous smile of an angel and the heart of a lioness: Sister Ruth Heaney, the Mother Teresa of Missouri prisoners. ${ }^{4}$ She knew the legislators, had periodically lobbied from capitol office to office for decades, and most of all, knew how the "game was played". She began contacting the senators ${ }^{5}$ that introduced the bipartisan sponsored Senate Bill $336^{6}$ and (22 co-sponsoring) representatives of House Bill $481^{7}$ in the $89^{\text {th }}$ General Assembly during the first weeks of 1997.

The next step was to generate support for the bills. The state Coordinating Board for Higher Education provided a roster of all the college presidents. Sixty personalized form letters were then sent out to these administrators in mid-March, 1997. An excerpted example of which follows:

This letter is in regards to pending House Bill No. 481 and Senate Bill 336, which would direct the rebate commission from the MDOC Inmate 
Phone-MCI contract to fund post-secondary education opportunities for the state's prisoners. The multi-year contract guarantees a minimum of $\$ 10$ million a year in rebates from this program. Instead of being added to the state general revenue, these funds could be invested in Missouri institutions of higher education.

Enclosed are copies of the legislation, topic broadsheets relating to the issue, and two short articles concerning the issue of prisoner higher education, previously funded by the federal Pell Grants. These documents will provide you with the necessary background to evaluate the efficacy of the situation. [...]

I strongly urge you to promptly contact your district's representative and senator, voicing your support for this legislation. As well, I suggest contacting the legislations' sponsors, advising them of your support and actions. Time is of the essence. Delays threaten the success of this most positive endeavour. [...]

Over the following weeks, several college presidents replied and included copies of their correspondence to their respective representatives. A sampling of these responses is as follows:

Thank you for your letter [...] alerting me to pending House Bill 481 and Senate Bill 336. I have spoken with lobbyists in Jefferson City and indicated my support for these bills. We will do what we can to encourage passage so as to provide educational opportunities for prison inmates.

Melvin George, Interim President (3-25-97)

Some educators responded by lobbying their representatives. For instance:

Dear Senator Edward Quick,

I strongly urge your support for Senate Bill \#336 that would fund postsecondary education for inmates. [...] This Missouri Bill probably won't affect Park College, because the state prisons in Missouri had worked with nearby state universities. However, I wanted to be certain you knew that I strongly support prison degree completion programs. I will happily testify at any hearing as an expert witness, or do whatever else I can.

[Signed] Don Bracken, President, Park College (3-24-97) 
Seeking a "hook" or wedge issue with which to leverage the concept with the legislature, propitiously (or maybe Divinely) Sister Ruth brought in the March 1996 article "It's our Christian duty to educate prisoners" from U.S. Catholic, which reported that the magazine's survey showed overwhelming support for sponsoring prison-based college programs. Obtaining a list of the legislators of the Catholic faith (a third of the sitting body), a lobbying packet was sent in April 1997 that detailed the following8:

This letter is in regards to HB 481 \& SB 336 concerning the refinancing of state prisoners' post-secondary educational opportunities via non-taxpayer dollars. The legislation would redirect the rebate commission from the MCI-Inmate Phone System contract from the state general fund to instead refinance postsecondary opportunities that were once supported by federal Pell Grants. [...]

Beyond the economic and social rationales for providing Post-Secondary Correctional Education (PSCE) opportunities, there is a moral imperative in doing so. Enclosed, among other fact sheets on this issue, is an article from U.S. Catholic magazine. Besides chronicling the value of PSCE programs and the Pell Grant controversy, the piece reports on a representative readership sample surveying their opinions on the issue. I would like to share some of those results with this letter. [...]

One response to this mailing was from Representative Norman Sheldon (4-29-97) stating that he "agree[d] with the concept of [my] letter and that PSCF is the best rehabilitative tool that can be offered as of today".

\section{WeLtPolitick}

Support for the legislation came from groups both in and outside of the state. The Public Policy Committee of the Missouri Catholic Conference (MCC) endorsed the bills. ${ }^{9}$ Julie Stewart, the president of the Washington-based Families Against Mandatory Minimums (FAMM) Foundation, offered to do whatever they could to support passage, commenting that the proposal was a "brilliant" idea and that was a concept her organization would "like to pursue with other states and maybe federally". ${ }^{10}$ Missouri Citizens United for the Rehabilitation Errants (MO-CURE) published notice of the bills in their newsletter as well. The Correctional Education Association wished us "good luck with the bill!" and requested progress updates. 
As with the prisoner-student Pell Grant eligibility being a controversial issue in the 1980s and 1990s, back room weltpolitick machinations influenced events around the efforts made to refinance education for prisoners. While passing out of the Senate Committee, the Bill 481 failed in its House Committee in 1997. Not only had the MDOC curiously failed to support the bills, ${ }^{11}$ but an illuminating incident also occurred in the capitol moments after the House Committee's vote. The following incident was relayed by Sister Ruth, as told to her by the representative involved. In an initial perceived-to-be, off-the-cuff confiding to one of the co-sponsoring legislators, the MDOC director cryptically commented, "It's too much money". Curiosity piqued, and acting upon a hunch, the freshman representative acquired a copy of the new phone contract and learned that the annual rebate had grown to a guaranteed minimum of $\$ 10$ million a year. Moreover, with the perpetual growth in the state's penal population, the projected rebate to the state's general revenue fund over the five-year life of the contract exceeded $\$ 60$ million!

Given that crucial piece of information, it became clear that if the "Sheepskins" legislation had been passed, the state would not only be denied tens of millions of dollars in non-taxed revenue, but prisoners would have the opportunity to earn fully-subsidized college educations. To some politicians the loss of the indirectly levied revenue traded for higher education to prisoners would be unpalatable. The rationale be damned! That seemingly off-the-cuff remark, lobbed over the shoulder in a "chance passing" in a capitol building stairwell, of "It's too much money", now made sense. Or as a representative who speciously justified his negative vote on HB 481 reasoned:

My philosophical problem with this bill is the funding of post-secondary education for our convicted felons. As soon as we fully fund college educations for all of Missouri's high school graduates [ignoring the fact that prisoners' collect phone calls would be funding their own education], I will reconsider my position [i.e., as in, when this improbable prerequisite criteria is met]. I cannot, in good conscience [or by logic or fairness; i.e., besides Pell Grants, prisoners are statutorily excluded in state and federal levels from student loans and state higher education grants], give to a convicted felon, that which we cannot give to the public at large. 
Despite the initial defeat, sponsoring legislators in both chambers expressed more confidence, with the experience gained from the previous session, in regards to passing the enabling legislation. Strategies were refined, coalitions constructed and reinforced, and resources marshalled. Realistically, we had been wildly successful in advancing our vision so far at a rapid pace. After all, less than 2 percent of all bills submitted in any given session ever make it to the Governor's desk for signing. Most do not even garner a committee hearing, much less a vote. In short, we were hyped at the prospects for the following session. However, it was at this point that the opponents of the measure instituted the most Machiavellian of actions to silence me.

\section{REPERCUSSIONS}

In June of 1997, one week after my promotion to the most reasonable prisoner position in the Missouri Department of Corrections, Resident Director of the Center of Braille and Narration Production, I was summarily transferred to the newest maximum-security, death-fenced enclosed penitentiary in the state's far northwest corner. While a shock, the transfer was not a total surprise. I knew that I had been picked up on the radar of those opposing the legislation. ${ }^{12}$

For the preceding years (out of my eighteen years of incarceration), I had survived in the 160-year-old Missouri State Prison ${ }^{13}$ - recently, if not magically, re-christened the Jefferson City Correctional Center - with only a single, very minor rule violation blotting my institutional conduct record. Moreover, I was an active board member of the Charitable Campaign Committee, which was responsible for collecting the prison's aluminium soda cans for recycling, raising over $\$ 10,000$ during my tenure for donation to area food banks. Additionally, I served as the media liaison for the Substance Abuse Advisory Committee, arranging print and broadcast coverage of several of the group's more beneficial programs, as well as those of other groups. The superintendent once commented, after watching the $\$ 3,000$ donation ceremony filmed by two television stations, that I was helping to give the public a non-stereotypical view of convicts. ${ }^{14}$ During all of this, I had also continued with my collegiate distance education pursuits.

My greatest achievement, however, had been to advance from narrator to narration supervisor to resident director of the Center for Braille and Narration Production. The CBNP is the oldest and most prolific prison-based program of its type in the country. The indirectly-supervised resident director is responsible 
for overseeing $\$ 50,000$ in computer, printer, recording and duplicating equipment with annual billings exceeding $\$ 70,000$, realizing a ten-fold plus multiple value in services delivered to those physically less fortunate. ${ }^{15}$

All of this was in my favour, and yet I was chosen to be shipped out, ahead of over 700 similarly eligible prisoners to complete the human consignment filling the newly opened prison. The day of my transfer, I received a phone call in my fifth floor office with a view of the state's shining capitol dome visible over the prisoner-built wall. The high-ranking prison administrator on the other end of the line commiserated with me over the fact that there was nothing to be done to stop the transfer. The order, he advised, had originated from the central office, and not at the prison's recommendation. "Your editorial and legislative activism," he ponderously stated, "had disturbed the status quo of the powers that be, and they want you as far from the capital as possible. Crossroads [the new prison] is about as far away as you can get". ${ }^{16}$

\section{The End Of The Line}

One week after my arrival at the new prison, I was rousted at midnight by three officers in my cell. In a quick series of moves during an ordered strip search, I was handcuffed, thrown into isolation (aka "the hole"), and charged with assault on staff and possession of marijuana. Even though the reporting sergeant admitted I had fully cooperated with all his orders, that I was not belligerent or resistive, and that I had not touched him, I was still found guilty of assault of staff, though not of possession. I was sentenced to one year in the hole with referral for criminal prosecution to boot.

Within days of starting my sojourn in the hole, I began receiving letters from the capitol. One of the co-sponsoring state representatives, Vicky Riback Wilson, wrote on July 30, 1997, confiding she had "heard" that I had been transferred and of her intent to re-file education funding legislation. "In addition to the supportive organizations you mentioned in your letter", she continued, "I have spoken to people from community colleges - Moberly, Three Rivers Lincoln University, and vocational programs. I think there is a strong coalition of supporters; however, they need to be organized and mobilized. I will check with Senator Flotron (R) so we can coordinate our efforts".

The next day, Senator Franc Flotron's letter of July 22, 1997, arrived. He wrote: 
The Senate version was voted 'Do Pass' in committee, but never was turned in for full Senate consideration...this will be on my list for submission [for next year's session]. My advice would be to continue working on the implementation material.

Then the follow-up letter from Representative Norman Sheldon - one of the sixty "Catholic" mailings - was shoved under the solid steel isolation door:

Thank you for writing me an informed and interesting letter concerning HB 481. The bad news is that the bill did not make it out of the Correctional and State Institutions Committee...I agree with the concept of your letter and that PGCE is the best rehabilitative tool that can be offered today. (June 29, 1997) [The chronologically reverse order of the letters' receipt is an example of the vagaries of prisoner mail delivery].

Entombed in the hole with all my resources in storage, I was now powerless to offer my knowledge, experience and support. I had been silenced. At least that was what the intended endeavour the state was to effect.

By the end of the year, working through the good auspices of Sister Ruth, "Calling for Sheepskins" was reprinted in the Cry Justice Journal, resurrecting the issue with a broader yet targeted audience. Thus, buried in the hole, denied access to all but a pencil and legal pad, limited to only handwritten correspondence for communication, I had found a way to energize the fight enlisting numerous supporters.

Days after the New Year commenced, Representative Vicky Riback Wilson wrote: "Thank you for informing me of the statistics of recidivism rates. [...] I appreciate your continued activism on this issue" (January 5, 1998). On January 15, 1998, House Bill 1372 was submitted for consideration. A month later, Representative Wilson updated me on the events. "As you suggested", she wrote, "Representative Troupe and I discussed lowering the percentage of funds available for education to 25 . However, we decided to start with the whole amount since it would be easier to reduce it later rather than increase it" (February 17, 1998). Although the bill eventually advanced further in the committee process, with the chairman now supporting the legislation, it failed to be scheduled for a full floor vote.

Concomitantly, the repercussions continued. Two days before Christmas 1997, I was transported to the county seat and arraigned on felony charges 
of Class B assault and Class C possession of 0.18 grams of marijuana (i.e. less than half the weight of a disposable packet of pepper). The initial plea bargain offer was for 20 years to run consecutively (a.k.a. "wild") to my current sentence. Dismissing the Public Pretender, cashing in a mutual fund I had been investing in for a decade as my eventual "gate money", I hired a notoriously rabid attorney known as the "Matlock of Missouri". However, by highlighting the availability of assets, the state Attorney General correspondingly filed an incarceration reimbursement forfeiture action against me, eventually seizing the remainder of my hard-earned, carefully invested and long-hoarded savings. The filing and timing of the state's civil action seems more than a mite coincidental. ${ }^{17}$

By the summer of 1998, I had won my grievance appeal, having the director herself dismiss my staff assault violation (only after serving ten months of a year-long sanction though). The criminal case was dismissed a week before trial, based primarily on my earlier filed pro se motions requesting an incamera review of the charging officer's personnel file and chain of evidence challenge regarding the alleged marijuana (i.e. it had disappeared somewhere along the way - imagine that). Moreover, we now had irrefutable evidence of forgery with conspiracy implications regarding the original Conduct Violation charging form. The pièce de résistance in all of this being the charging sergeant's demotion and his subsequent dismissal with cause, whereupon he was unable to obtain similar employment in other correctional systems.

Yet, the latest house bill had failed, again. With further changes in the phone contract system, thankfully eliminating the rebate and thus lowering overall charges, my transfer from one prison to another, ten months in the hole on trumped up charges, and lack of solid organizational support, I was unable to prosecute the campaign as effectively as I had been able to the previous year. The concerted multi-dimensional assaults orchestrated by the nebulous "powers that be" had achieved their assumed intent of effectively removing me from the lobbying process.

If we had been able to conduct an education and lobbying campaign via the prison branches of the National Association for the Advancement of Coloured People (MO-CURE), Families Against Mandatory Minimums (FAMM) and Missouri Association of Social Workers (MASW), these significant resources could then have likely built upon the group work already laid, making a major push for the legislation's passage. If not for passage of the specific legislation, then for serious debate regarding the 
lack of higher education opportunities in the state's prisons. As it was, and continues to this day, there is virtually no legislative cognizance of the supreme value and corresponding paucity of correctional education in the Show-Me State. ${ }^{18}$ In fact, in 2005, all education programs (i.e. remaining Adult Basic Education and General Equivalency Diploma) were removed from three of the state's maximum-security prisons, leaving them no educational or vocational training programs at all.

The swan song of the "Sheepskins" legislation occurred in 1999, with the submission of yet another bill. In my admittedly half-hearted efforts to support, the speaker of the house responded to my inquiry:

A particular piece of legislation that accomplishes your concern has been introduced by Representative Quincy Troupe, Vicki Riback Wilson, Mike Schilling, Bill Gratz, Wayne Crumo, Sam Leake, and Amber Boykins and referred to the House Committee on Correctional and State Institutions. HB 601 requires up to $40 \%$ of any profits made by the state from long distance calls be placed in the telephone-education fund. The money from this fund is used for the post-secondary education of inmates (February 22, 1999).

This bill, too, failed to pass.

\section{Analysis}

This case study chronicles on the one hand the failure to have legislation passed into law, and on the other it demonstrates what one little old lady, a prisoner and a few friends donating stamps can accomplish with a viable idea, detailed planning, and perseverance in execution in the pursuit of a dream.

The errors in our strategy in retrospect were committed in ignorance, procedural oversight and lack of organization resources. First, we should have drafted the specific legislation ourselves and submitted it to the sponsoring legislators. This way both bills would have been worded identically, thus eliminating the necessity of the language reconciliation procedure between the chambers' bills if they had been passed.

Second, as much as we tried to educate the legislators on the issue, imparting a more profound analysis might have made a difference. We needed 
more lobbyists and more face time in Q \& A debate not only with supporters, but more so with opponents. We needed to push for committee hearings on the legislation and then prepare ourselves to provide informed testimony.

Third, we needed to organize an even greater "voter" lobbying campaign encompassing endorsement letters, emails and phone calls to legislators' offices. On issues such as this, half a dozen to ten contacts on a specific bill would be unusual, and thus attentive of larger support. Politicians are sensitive to future votes. Even if a particular legislator disagrees with the pending bill, their response in itself is informative, offering opportunities for well-crafted rebuttals to stated objections, and thus hopefully converting them to allies. And if not so persuaded, they identify themselves as those to campaign against in the subsequent election.

Finally, we needed more resources and especially organizational allies. This requires a lot of effort, negotiation and long-term planning. At times, it can seem like trying to herd cats! But together, with those of us on the inside working with those who advocate for a more inclusive and rehabilitative correctional system from the outside, effective legislative conditions can be built. ${ }^{19}$ It is up to $u s$ to accomplish such achievements.

\section{Afterword}

This article, as well as the majority published herein over the past twentyfive years, would only have found voice in the Journal of Prisoners on Prisons (JPP). The audacity of the founding editors to create an academic standard, peer-reviewed periodical for prisoners' research, opinions, and insights of those from within the gulag archipelago of the prison-industrial complex was tantamount of the highest hubris prevailing against the zeitgeist of the era. The perseverance of the subsequent editorial boards has been in unvarnished perpetual support pursuing intellectual inquiry within the expansively viewed academy in philosophical concurrence to the Pedagogy of the Oppressed. Without these essentially unknown folks of liberal morality, academic ethics and good will, my voice and the value of that voice as well as hundreds of other prisoners' voices over the years would have never been heard, much less recorded and added to the common body of knowledge.

Yet, even this periodical in its loving process of production, exemplifies the very need for the JPP. Of all the academic journals my work has been 
published by, the journal's blind, peer-reviewed process has been the most professional in format and incisive in assisting me to produce the best of my submitted work. In this process, however, the gulf of demarcation between the free and the imprisoned reveal itself.

I am immensely grateful to the anonymous reviewers of this article's manuscript. It is a better, more coherent piece because of their insightful comments and suggestions. From their comments I can assume they are professional academics with experience in the related fields of criminology and criminal justice. Their comments also reveal the disconnect between even the best educated of our ensconced worlds and those of us in the steel cages we actually struggle to survive in.

One reviewer wrote that the only question they had concerning the piece was that "the body of the narrative is very critical of the correctional system's efforts to silence and suppress the author's activity around legislative change and making education accessible to prisoners, while the conclusion's analysis focuses solely on how the campaign could have been strengthened on the part of the organizers". My initial response to such was "well, like, duh". That is the purpose of the piece. It is what transpired: the good, the bad, and the ugly. My goal is to chronicle this history, and to offer a template of how others may be able to adapt efforts to create change from within. For me this has always been a mission facet of $J P P$.

Another reviewer comment concerned the degree to which the piece contributed to the literature. They freely admitted they were unfamiliar with the "existing literature on political organizing inside prisons" (and ensuing state repression), or access on education for prisoners in the U.S. My response to this was that neither am I familiar with such literature, other than spotty, circumstantial exposure to such. Rarely, and then only briefly mentioned, is such information cited in the mainstream texts and journals. It is another reason I wrote the article.

As to the publication decision, one reviewer's comment was to question if the author's mention of his institutional charges and transfer were "pertinent to the larger narrative and commentary". My response to this is that it has been my perception that all of this had a direct causal relationship. If I had not been an "uppity inmate" not knowing my place in the scheme of things in the status quo, I would most likely never have been transferred and "free cased" with the guard assault and ridiculous possession charges. Moreover, those charges if enforced would have essentially meant I would never be 
released from prison. So, yes, I have visceral as well as intellectual reasons for believing the comprehensive narrative is critical to the comprehension of the piece's narrative.

The reviewer's comments also reminded me of my American parochialism, and the necessity to write for the international audience that $J P P$ serves. The reviewers also suggested a comprehensive reading list of related materials as being beneficial. ${ }^{20}$ It sure would be. Part of the purpose of this piece is to chronicle the experience and by doing so highlight the isolation prisoners and even activists endure in their efforts to affect change. The reviewer's comments also suggest a disconnect between the academic world with an abundance of immediate research resources and that of prisoners' with the description of extreme paucity of such being a gross understatement.

Again this reinforces the need for the great service $J P P$ provides to the common body of knowledge to record such experiences. Without the extensive library that $J P P$ has now published, this voice and hundreds of others with stories and views to tell would have been lonely shouts into the vastness of state sponsored repression. This forum is more relevant than ever, and needs to be read by a much wider audience. It should be part of every criminal justice major's supplemental reading list, if not part of a course curriculum in corrections.

\section{ENDNOTES}

1 The Cry Justice Journal is published by the New Life Evangelical Center of Larry Rice Ministries. The publication had a circa print distribution of 10,000 , with extensive institutional pass-along readership. A decade later, the publication was banned from the state's prisons, while it is now wholly published online. The article was also published, under the title of "Dialing for Diplomas", as a two-part series in the March and April 1997 issues of Justicia.

2 At the time, I worked as the Narration Supervisor in the Center for Braille \& Narration Production (CBNP) at the Jefferson City Correctional Center, which was located four blocks from the capitol building. The CBNP was a 20-man operation contracted by the state's Bureau of the Blind which we programmed Braille transcribing computers, having the output double-sided impact printed, collated and bound; narrated books onto cassette tapes, duplicated and Braille labelled; and scanned or input keyed, edited and produced large print orders. In 1996, the CBNP narrated 65,000 pages of text, transcribed over 70,000 pages of Braille and formatted 80,000 pages of large print documents, providing over $\$ 1$ million in market-rate services for the visually impaired citizens of the state. I chronicle this environmentally unique 
work assignment, because it provided access to desktop publishing equipment and spiral binding facilities that are generally not directly available to prison populations. Thus, I was able to professionally produce twenty-five, 100-page briefing manuals for our lobbyist's targeted use.

\section{TABLE OF CONTENTS:}

I. Proposal Article: "Calling for Sheepskins in Missouri Prisons". The Golden Rule of Advocacy

II. "Truth about prisons could change things". National Catholic Reporter (July 26, 1996)

"Prison Economics: Reality Bites". Justicia (July-August, 1996)

III. "There ought to Be a Law (but Not This Crime Bill)". The New York Times (August 24, 1994)

"It's our Christian duty to educate prisoners". U.S. Catholic (March 1996)

"Deny Pell Grants to Prisoners? That Would be a Crime". Criminal Justice (Summer 1994)

IV. "Post-Secondary Correctional Education: An Evaluation of Effectiveness and Efficiency". Journal of Correctional Education (September 1992)

"Should Prisoners Have Access to Collegiate Education? A Policy Issue". Educational Policy (September 1994)

4 A pioneer in the Catholic Worker movement, a widow since 1950 and founding member of the Missouri Commission on Human Rights in 1957, she became Benedictine in 1974, after her six children were raised. Sister Ruth invested decades in daily visits to Missouri prisons, bringing her endless agape to thousands, and conducting Alternatives to Violence and Positive Mental Attitude workshops, while leading weekly ecumenical Journey in Faith discussion groups, which is where I first encountered her. She helped establish Agape House, a hostel in the capital where people visiting imprisoned loved ones could economically spend the night. In 2005, Sister Ruth received the Missouri Association for Social Welfare Humanitarian Award. In her acceptance speech, she remarked that "prisons are places of structured dehumanization. People in prison live under constant deprivation of things people really need, as well as humiliation around the clock". Over her ministry, she was "permanently" kicked out of Missouri prisons four times. By 2002, though, the administration and prisoners celebrated Sister Ruth Heaney day and established an award in her honor for exceptional volunteer services to penal populations. This blessed woman of infinite spiritual joy passed away in 2006, having more than any other human being positively affected generations of Missouri prisoners. Sister Ruth is dearly missed.

5 One was a childhood friend of an associate of mine at the prison and activist in many community programs. This prisoner (co-founder of the MDOC's immensely successful Intensive Therapeutic Community program) provided an introductory/ endorsement letter to the respected conservative politician that I believe was crucial in convincing the senator not only to co-sponsor the bill, but also to recruit a bipartisan co-sponsor. The important facet in this story is that such familial and friendly relationships between prisoners and the various elements in the establishment exist in every system. Focused utilization of such contact can mean the difference between fair consideration of proposals and the stonewalling of legislation. 
6 (SB 336) AN ACT - To amend chapter 217, RSMO, by adding thereto one new section relating to offender education.

1. The department shall establish a fund to be known as the "Post-Secondary Education Fund" to assist offenders who want to pursue post-secondary education. 2. The department shall deposit all profits collected from the operation of the inmate phone system into the post-secondary education fund. The monies in the fund shall not revert to be transferred to general revenue, notwithstanding the provisions of section 33.090, RSMO, to the contrary. The department shall maintain accurate records of the amount of monies in the post-secondary education fund and shall allocate monies from the fund to each correctional facility as needed.

7 (HB 481) AN ACT - Relating to education for inmates.

Section 1. Any profits received by the state from long distance calls made in facilities of the department of corrections shall be transferred to the director of revenue to be deposited in the "Telephone Education Fund" which is hereby created in the state treasury. Moneys in this fund shall be available, subject to appropriation, to be used for inmates' post-secondary education, in any format, offered by educational institutions which are accredited in Missouri.

8 Collectively, over 150 pieces of correspondence were posted relating to the 1997 legislative efforts. Even with the relative premium wages earned at the CBNP, this was a substantial personal expense. To utilize the CBNP production facilities, I had briefed an entire staff, which had unanimously voted to support the project. This also included their donations of postage. I mention this seemingly trivial aspect because efficient and creative use of limited resources is critical for prisoner activists. Enlisting allies for brain storming sessions, moral courage, and access to shared assets from contacts to copying and typing to even stamps can quite likely make the difference between a grandiose idea and realistic shot at changing a small part of the world we inhabit.

9 Readership survey results from the March 1996 issue of U.S. Catholic:

* "Educating prisoners is one good way to reduce the number of criminals returning to prison". 91\% AGREE

* "Prisoners gave up their right to an education when they committed their crime". 87\% DISAGREE

* 'It makes good social and economic sense to put prisoners' time to good use by giving them an education". 87\% AGREE

* "Providing education for prisoners will make prison less of a deterrent". $\mathbf{8 2 \%}$ DISAGREE

* "Funds for education should go prisoners of all ages". 87\% AGREE

* "I believe it's our Christian duty to educate prisoners". 84\% AGREE

10 MCC's April 1997 newsletter, Good News, ran the column "Senate Committee approves funds to educate inmates". The story detailed, "In testimony to the Committee Senator Flotron noted this would be an appropriate way to fund college programs because the money is generated from inmate families rather than State funds. Studies show that inmates receiving college education have a lower recidivism rate than other inmates" (p. 3).

11 In a matter of conjecture, I have pondered why a bureaucrat would not support an off-appropriation $\$ 10$ million budget increase. The director was the former deputy director of NY-DOC and had overseen that state's then nationally exceptional PSCE 
program, and thus knew the programmatic and rehabilitative value of the opportunity. Due to supplant/supplement budgetary games played during her administration of the MO-DOC, Missouri prisoners had been among those in a handful of states who had lost the Pell Grant eligibility a year before than the blanket national expulsion. This new funding source would, in turn, provide a five-fold $(500 \%)$ increase in post-secondary funding over what was received the last year the state's prisoner students had received in Pell Grant financing. This non-direct tax generated funding would provide an Ivy League-level of PSCE programming. Why would a DOC director and a professional bureaucrat turn down such "free" largesse? My theory is that a sub rosa political deal was made. What the specific arrangements for quid pro quo are unknown, but the legislature's powers that be did not want to give up these multi-millions in non-levied dollars. Why else would such an experienced corrections professional abandon the opportunity to creatively finance the premiere Post-Secondary Correctional Education program in the nation? Why indeed.

12 A few weeks after the second mass mailing, by happenstance (but perhaps by arranged coincidence in retrospection) I crossed paths with one of the prison's internal investigators. We had never interacted. Not even knowing his name, but nonetheless thoroughly aware of who he was, we exchanged polite nods as we awaited the central wheelhouse to open a gate. Out of the blue, he observed, "those were a lot of letters that went out to the legislature." Turning to look up at this gargantuan man, I replied, "Yes, there were many". Since these had been sent to public officials, I was able to post them in sealed envelopes, as opposed to unsealed and searchable ones as policy dictated for general correspondence. I had no illusions that the prison had not surreptitiously opened at least some of the sixty to learn what was being sent out. At the time, I gave the chance encounter no serious consideration that the administration would read the contents, because it was similar to what I had openly sent to the college presidents a few weeks earlier. In a (later perceived as chilling) parting shot, he quipped, "Go with God". This was a reference to the "Catholic" nature of the mailing, letting me know that they had indeed read the mailings. It was a message. The system made sure I knew that they knew what I was doing. And later with my transfer and subsequently arranged nightmare, perhaps I should have less hubris. Then again, by that time, it was already too late - and like Paul Newman's character of Cool Hand Luke, I hate being bullied by the system.

13 See ibid.

14 The Missouri State Penitentiary was once labelled "the Bloodiest 54-Acres in America". Though these lurid times had passed before my transfer there, "The Walls" were nonetheless a hardcore place to do time.

15 At the time, I took that as a compliment. Soon thereafter, however, I had cause to reason otherwise. Ironically, because of my apparent media aplomb, the superintendent requested that I interview him for the closed-circuit channel ("Jefftown"), regarding his tour of the soon to be opened Crossroads Correctional Center. A few months later, I received my own on-going tour of this patch of Missouri.

16 He actually talked like this. He was one of the most equitable penal administrators I have ever met. If he could be sold on the value of a program and an operationally logical outline, he would facilitate its enactment. Because he was viewed as too "pro-prisoner", by the same "powers that be" no less, he was never promoted higher 
than deputy superintendent. Never thought I would say this about a "screw", but I long for the proverbial good old days of his "correctional administration".

17 In clear violation of constitutional ex post facto protections (the seizure law had been passed eight years after my conviction), the courts ruled in the state's favour and seized assets. Two years later, after receiving a publisher's \$1500 reprint rights check, the Attorney General filed another action. This time in pro se filings I succeeded in having the suit dismissed as insufficient in meeting the statutory criteria. A year later, the Attorney General flew an assistant to Maine to serve filings on the publisher of the first two editions of my book, The Prisoners' Guerrilla Handbook to Correspondence Programs in the United States \& Canada (a project I had also initiated while in the hole on the trumped-up guard-assault charges). That case, too, was summarily dismissed. In 2007, the Attorney General, utilizing evolving legal interpretations and strategy froze my institutional account for over a year, garnishing 90 percent of all income in perpetuity of my incarceration, with the intentions of garnishing 20 percent of my post-release income until the $\$ 400,000$ of the then estimated cost of my incarceration, if it was held the entire length of sentence, was collected. With the deft assistance of the only attorney in the state with experience regarding this particular statute, all by the initial proceedings were dismissed, and all assets except the initial forfeiture were returned in 2009, eleven years after the original filing.

18 Missouri's state nickname, like the "Golden State" is California's.

19 An absolutely intriguing story expanding upon this concept is told in Jamie Pissonnette's When the Prisoners Ran Walpole: A True Story in the Movement for Prisoner Abolition.

20 One reviewer's suggested reading is Munn, Melissa and Chris Bruckert. (2010) "Beyond Conceptual Ambiguity: Exemplifying the 'Resistance Pyramid Through the Reflections of (Ex)Prisoners' Agency”, Qualitative Sociology Review, 6(2): 137-145.

\section{ABOUT THE AUTHOR}

Jon Marc Taylor, $\mathrm{PhD}$, has been a prisoner for the past 30 years and has received The Nation / I.F. Stone and Robert F. Kennedy Journalism awards for his reporting on correctional issues. In 1989, Taylor's first piece in the Journal of Prisoners on Prisons, "The Economics of Educational Rehabilitation", appeared in Volume 2(1). 